\title{
THE MOHAMMEDAN CONCEPTION OF SAINTSHIP
}

(The following are extracts taken from some examination papers sent in by students of the Cairo Study Centre, after a course of lectures given by Mr. George Swan, entitled "An Introduction to the Study of Mohammedan Mysticism," in reply to a question as to wherein lay the fundamental errors in the Mohammedan conception of Saintship. The lectures had been provocative of thought rather than a full statement and the questions set with the object of discovering how far they had been successful therein. Ed.)

ALL non-Christian faiths that have a definite conception of saintship differ from Christianity in one respect at least. To Christianity, as our Lord showed, it is not an abnormal thing, it is normal.

But to go behind this statement, we can see that the Christian conception of saintship has its roots in the fundamental difference between Christianity and any other faith. For surely it is an error to suppose that any human being can be a saint by his own efforts towards piety, devotion, renunciation, powers of miracle working, ecstacy in worship; asceticism and so on. These things must be worthless without the God-given spirit of holiness and how can any true Moslem realize this? For Christian saintship simply means the living in Communion of Spirit with the Father, even as the Son always did; and saintliness is a human word which we use when we try to express an inexpressible thing, the dwelling of God's spirit in a man, "Because ye are sons-God hath sent forth the Spirit of His Son into your hearts

Now all this seems far enough from the subject of the Moslem conception of Saintship. But I think we see from it that the human impulse towards holiness which manifests itself in abstinence, devotion, contemplation of the invisible, meditation, etc., is only of any use when it is met by the Divine impulse, which fills it and uses it 
as a vehicle. Such a meeting takes place from time to time on a great scale; such was the case with John the Baptist; we have seen it on a smaller scale since then. God does use this, as he uses all human means of religious expression. And in so far as it is used by $\mathrm{Him}$ it is a glorious and a good thing. But it is not all there is of saintship and here a comparison of the methods of our Lord and those of John the Baptist is very helpful and suggestive.

There is no need to point out fundamental errors in a "Saintship" which has degenerated from a desire to be holy into a desire to be considered holy (think of our Lord's plain words to the hypocrites) and still less need with regard to those who use "saintship" as a cloak to mask evil things.

There is food for thought in the fact that certain races have this quality of so-called mysticism more or less strongly developed; and that, especially in India, where it reaches its highest development, one must be careful to distinguish how much of it is racial, temperamental, part of their atmosphere, as it were, part of their spirit's way of expressing itself, how much of it really something to be rejected and how much is something to be caught hold of for the kingdom of God.

J. M. S-M.

The first fundamental error must be "the Way" itself, seeing there is but one appointed "Way" to God. The one mediator between God and man-even the man Christ Jesus.

Their "Way" says nothing about living one's ordinary life in the world. Its doctrine is too esoteric; attainable only by the few. The three stages are: (1) PurgativeThe killing of desire for all but God; (2) IlluminativeGradual enlightment of the soul; (3) Unitive-Gradual absorption into the Deity. Contrast with this the Christian "Way" and the Christian life. The way through Jesus Christ the life-loving God with all the heart and une's neighbor as oneself.

Some mystics held that the body, being material, was 
essentially evil and formidable and therefore might be given license to do as it would. Contrast St. Paul's "make your bodies instruments of righteousness." And, "Your bodies are temples of the Holy Ghost." Their conception of God was based largely on fear. The way of approach is therefore hard and tortuous and holiness was with a view to escaping the torments of hell. The unitive stage meant the loss of personality and even individuality. Compare the saying of one mystic, "God is I," or "I am the Truth," leading to the gross pantheism.

With a view to assisting the soul to return to the God from whence it came, artificial means, such as self-hypnotism and the Zikr are freely used.

Those who have the way are considerd as holy beyond compare, and this leads to charlatanism and fraud; such holy men are freed from all laws of restraint incumbent upon other men, while others buy access to God or become holy by proxy.

A. J. M.

Many of the early Moslem saints believed that the first essential towards becoming a saint consisted in renouncing all the affairs and interests of the world and concentrating all desire on God alone. This extreme otherworldliness carried with it a concentration on the self, an introspectiveness, so that all their intellectual life was of a subjective character. The objective study of the outside world was neglected and men went far astray following their devices because they argued from incorrect premises. Another grave error was that a seeker put himself slavishly and absolutely under the direction of his teacher who completely controlled all his actions and, in fact, usurped the place of conscience and of God Himself in the mind and heart of the disciple. There was no scope left for the leading of the Spirit of God. All the exercises and instruction to the disciple were directed towards producing a state of ecstacy, under which it was believed the veil of the flesh was removed and the ecstatic saw into the verities of eternal things. This training involved the giving up of personality, the 
cessation of all reasoned thought, indeed the deliberate ruining of all that we consider valuable in Christian character.

The whole business of saintship was only for the favoured few, and the early Sufis especially were very exclusive and esoteric; only a very few could ever hope to reach the state of ecstacy, that is, could come into touch with the spiritual world where God's will is to be found out. When we contrast these ideas with the Christian ideals we see how far short they fall.

In Christianity we have a Saintship open to all who will; a full active life in the world (though not of it) freely sharing the life of God in Jesus in Whom we live and $\mathrm{He}$ in us. Who is the vine and we His branches with His life in us. And we have one meditator between God and man, in whom dwelleth all the fullness of the Godhead bodily. Contrast with this the long line of intermediaries in the dervish systems.

The idea of the "Karamat" of the Auliya is a very important one practically in the Moslem conception of saintship. The absence of a critical attitude in Islam has made possible the hopeless jumble of absurd, incredible "wonders" mixed with a smaller number of genuine "wonders." These holy men having power of working wonders are consequently feared and served and often worshipped by the common people. Thus is diverted from God much of the honour He alone should have. The Moslem Saint is not one who has won the victory over sinful human nature by battling with temptations; but has simply dropped all worldly things to seek for his own individual salvation which in the end turns out to be absorption into the Great Spirit.

J. E. B. 